\title{
SYNTHEISIS OF THE ZrB2 2 -SiC ULTRA-HIGH TEMPERATURE CERAMIC POWDER BY PLASMA SPHEROIDIZATION
}

\author{
1,2Ivan GONCHAROV, ${ }^{1}$ Nikolay RAZUMOV, ${ }^{1}$ Nikolai OZERSKOI, ${ }^{1}$ Aleksei SILIN, \\ ${ }^{1}$ Tagir MAKHMUTOV, ${ }^{1}$ Artem KIM, ${ }^{1}$ Anatoly POPOVICH \\ ${ }_{1}^{1}$ Peter the Great St. Petersburg polytechnic university, St.Petersburg, Russian Federation, \\ 9670522@mail.ru \\ 2 Politecnico di Milano, Milan, Italy, ivan.goncharov@polimi.it
}

https://doi.org/10.37904/metal.2020.3606

\begin{abstract}
The mixture of $\mathrm{ZrB}_{2}$ and $\mathrm{SiC}$ powders were used as a raw material. The powders were milled in a planetary ball mill, blended with polyvinyl alcohol, and sieved to 0-125 $\mu \mathrm{m}$. After sieving, the powder was spheroidized in Tekna Tek 15 ICP plasma plant. During the spheroidization, the ceramic powder melts and form a compound, containing $\mathrm{ZrB}_{2}-\mathrm{SiC}$ and rapidly crystallized forming dense spherical shaped powders, suitable for additive manufacturing or sintering techniques.
\end{abstract}

Keywords: UHTC, additive manufacturing, powders, plasma spheroidization

\section{INTRODUCTION}

Ultra-high temperature ceramics (UHTCs) are candidate materials for a variety of aerospace applications owing to their unique combination of properties, including high melting temperature $(>3273 \mathrm{~K}$ ), high strength, and high elastic modulus [1-6]. Among them, Zirconium diboride $\left(\mathrm{ZrB}_{2}\right)$ is an outstanding material owing to its high melting temperature $(>3000 \mathrm{~K})$, low theoretical density $(6.09 \mathrm{~g} / \mathrm{cm} 3)$, high thermal conductivity $(65-135$ $\mathrm{W} / \mathrm{mK}$ ) and relatively low thermal expansion coefficient [7]. Above $1400^{\circ} \mathrm{C}$, however, the oxidation resistance of pure $\mathrm{ZrB}_{2}$ is very poor due to the volatilization of $\mathrm{B}_{2} \mathrm{O}_{3}$ and a residual porous $\mathrm{ZrO}_{2}$ layer [8]. Adding $\mathrm{SiC}$ can significantly improve the oxidation resistance of $\mathrm{ZrB}_{2}$-based coatings in the moderately high temperature range by the formation of borosilicate glass [9].

As a result of its strong covalent bond and low self-diffusion coefficient, it is challenging to fabricate the nearly fully dense $\mathrm{ZrB}_{2}$-based ceramic or dense $\mathrm{ZrB}_{2}$-based coating [10,11]. For sintering the $\mathrm{ZrB}_{2}$-SiC ceramic, the main preparation technologies include hot pressing, reactive hot pressing, pressureless sintering, and spark plasma sintering (SPS) [12-15]. Until now, to further improve the densification of the $\mathrm{ZrB}_{2}-\mathrm{SiC}$ ceramic, adding sintering aids and adjusting sintering parameters have been tried in several previous works. As for the $\mathrm{ZrB}_{2-}$ $\mathrm{SiC}$ coating, many methods, including plasma spraying [16], vapour silicon infiltration (VSI) [17], painting slurry [18], in situ reaction [19], and pack cementation [19]. Wang et al.[20] designed a gradient structure and prepared a dense and defect-free $\mathrm{SiC}-\mathrm{ZrB}_{2}-\mathrm{MoSi}_{2}$ coating on $\mathrm{SiC}$ coated $\mathrm{C} / \mathrm{C}$ composites using supersonic plasma spraying. Lietal. [21] introduced a relatively low melting point WB into $\mathrm{ZrB}_{2}-\mathrm{SiC}$ coatings to improve the densification and oxidation resistance of the coating. The eutectic $\mathrm{ZrB}_{2}-\mathrm{SiC}$ composition powder were obtained by plasma spheroidization for spray spraying [22].

In this work the results of synthesis of the $\mathrm{ZrB}_{2}-\mathrm{SiC}$ spherical powders from elemental powder mixture by plasma spheroidization are presented. 


\section{MATERIALS AND METHODS}

The elemental powders of $\mathrm{ZrB}_{2}$ and $\mathrm{SiC}$ were used as raw materials. The powder mixture of $80 \mathrm{ZrB} 2-20 \mathrm{SiC}$ (vol\%) was blended in planetary ball mill Fritsch Pulverisette 4 with the addition of 5 (vol\%) of the Polyvinylalcohol (PVA) as a binder reagent. After the milling, the mixture was sieved into the 0-125 $\mu \mathrm{m}$ fraction with subsequent plasma spheroidization in $15 \mathrm{~kW}$ ICP plasma torch (by Tekna Plasma Systems inc.) with powder feed rate $4 \mathrm{~g} / \mathrm{min}$ in argon-hydrogen plasma. The phases were analyzed by XRD Bruker D8 ADVANCE. The microstructure of samples was characterized using SEM Mira3 Tescan. The chemical elements distribution was studied by $\mathrm{X}$-ray elemental mapping.

\section{RESULTS AND DISCUSSION}

Figure 1 shows the $\mathrm{ZrB}_{2}-\mathrm{SiC}$ phase diagram [6]. The addition of the $\mathrm{SiC}$ leads to a decrease in the melting temperature and form the eutectic composition. The XRD results (Figure 2) shows the diffraction peaks of the $\mathrm{SiC}, \mathrm{ZrB}_{2}$ and the presence of the $\mathrm{Si}$ and $\mathrm{C}$. The latter may be the signs of the dissociation of the $\mathrm{SiC}$ under the high-temperature plasma treatment.

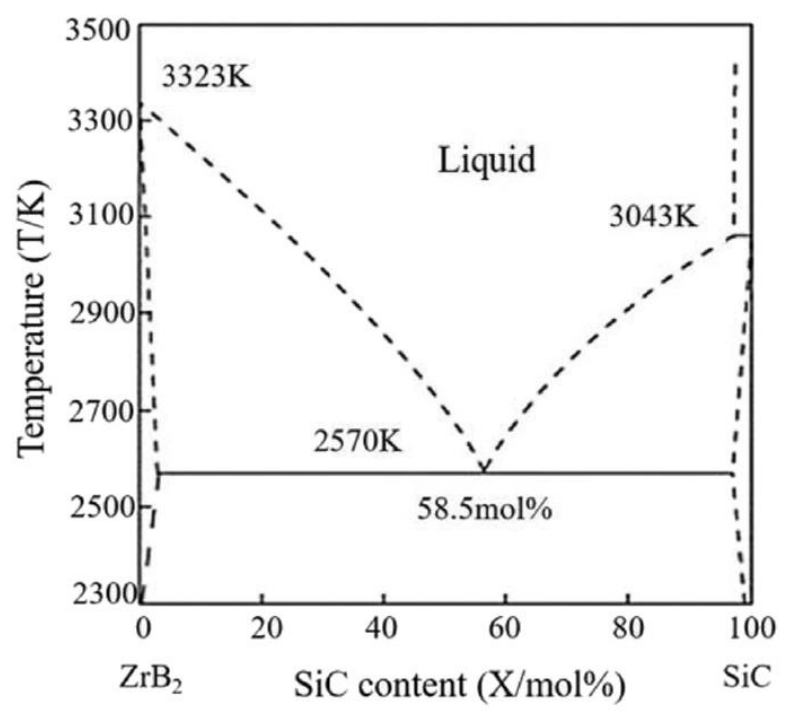

Figure $1 \mathrm{SiC}-\mathrm{ZrB}_{2}$ phase diagram [6]

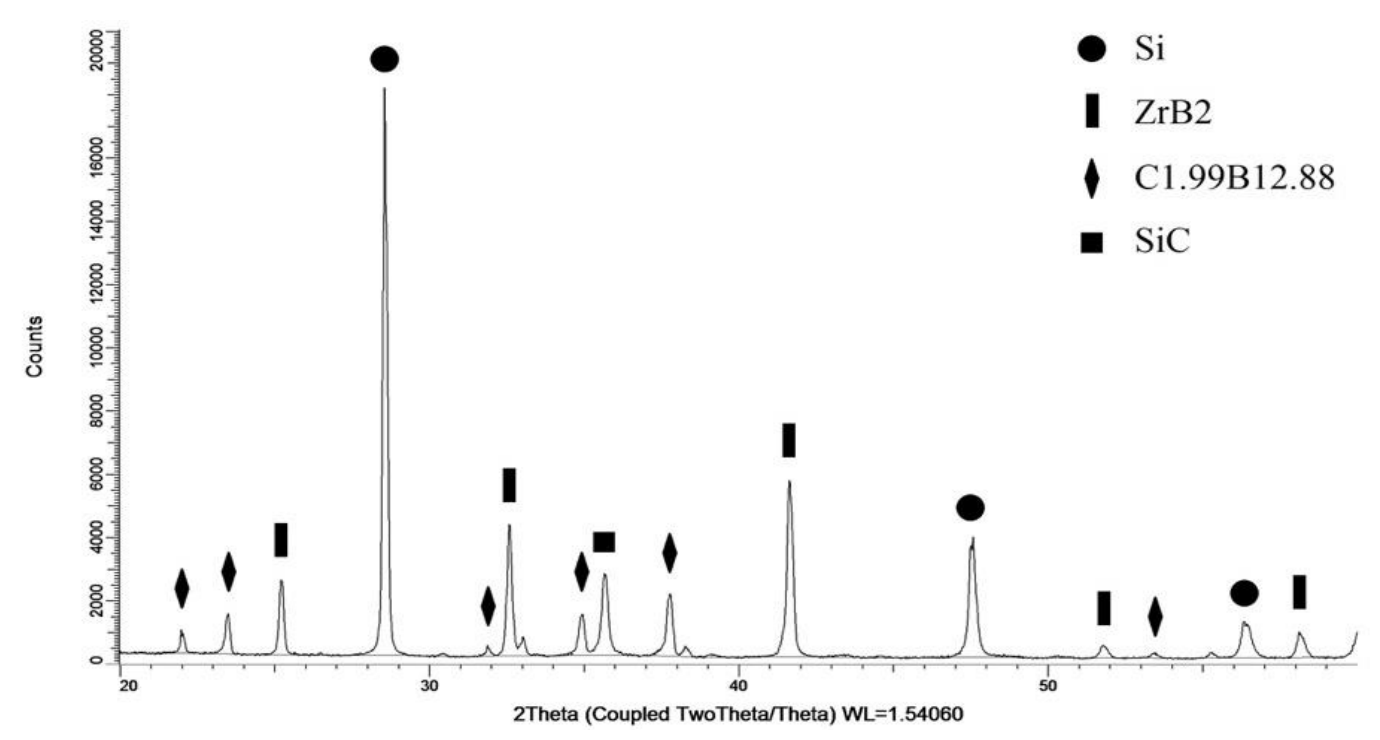

Figure 2 XRD pattern of the powder after plasma spheroidization 
The morphology of the powders after plasma spheroidization is presented by near-ideal spherical shape particles with the presence of nanoparticles that agglomerated around the particles due to the electrostatic interaction (Figure 3). Those nanoparticles are the result of overheating, vaporizing and condensing of the smaller particles in the fraction and the decomposition of the PVA with the resulting carbon nanoparticles. On the surfaces of the particles, it can be noticed the signs of the epitaxial growth of the ceramics.

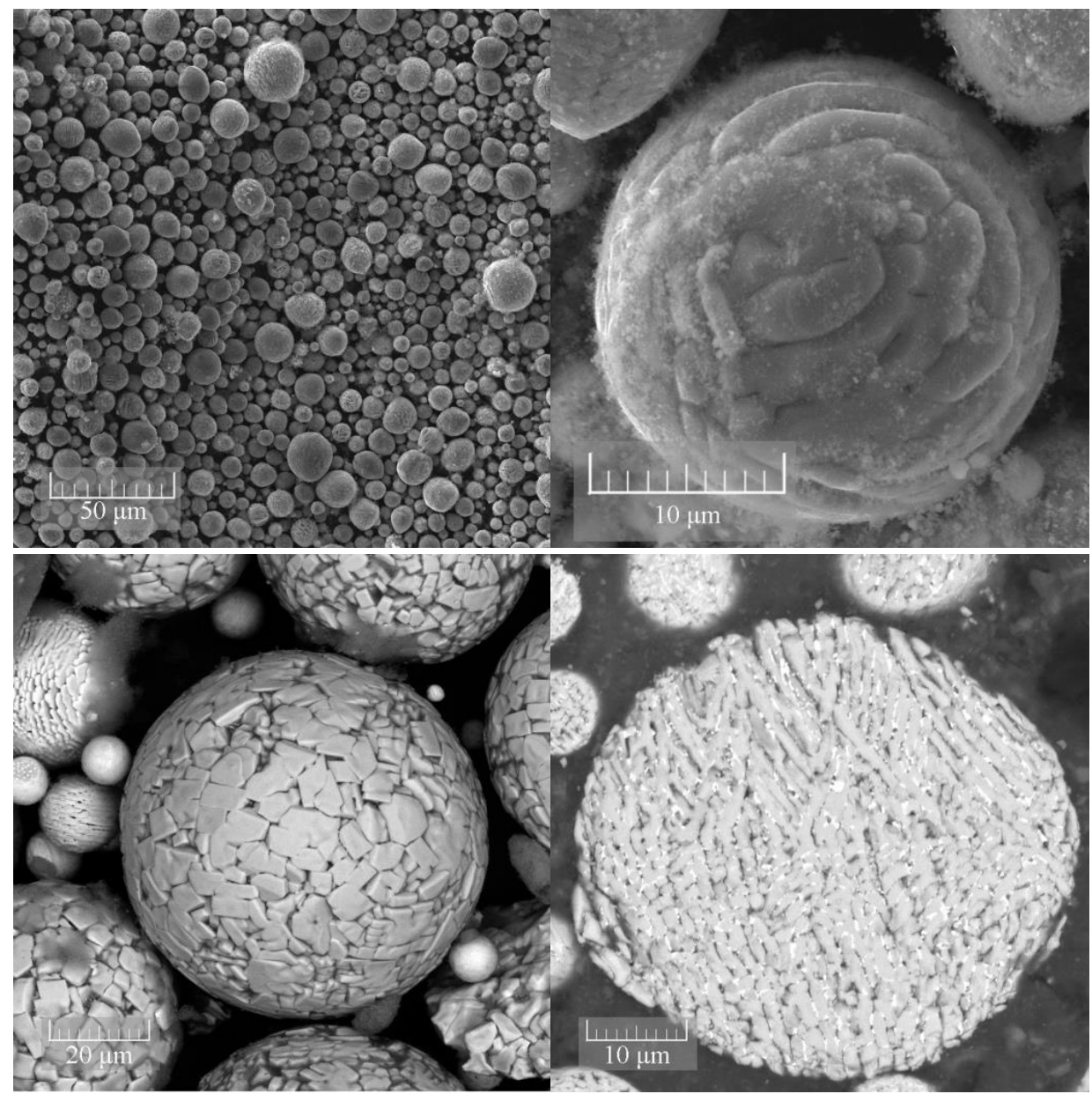

Figure 3 SEM micrographs of the powder after plasma spheroidization

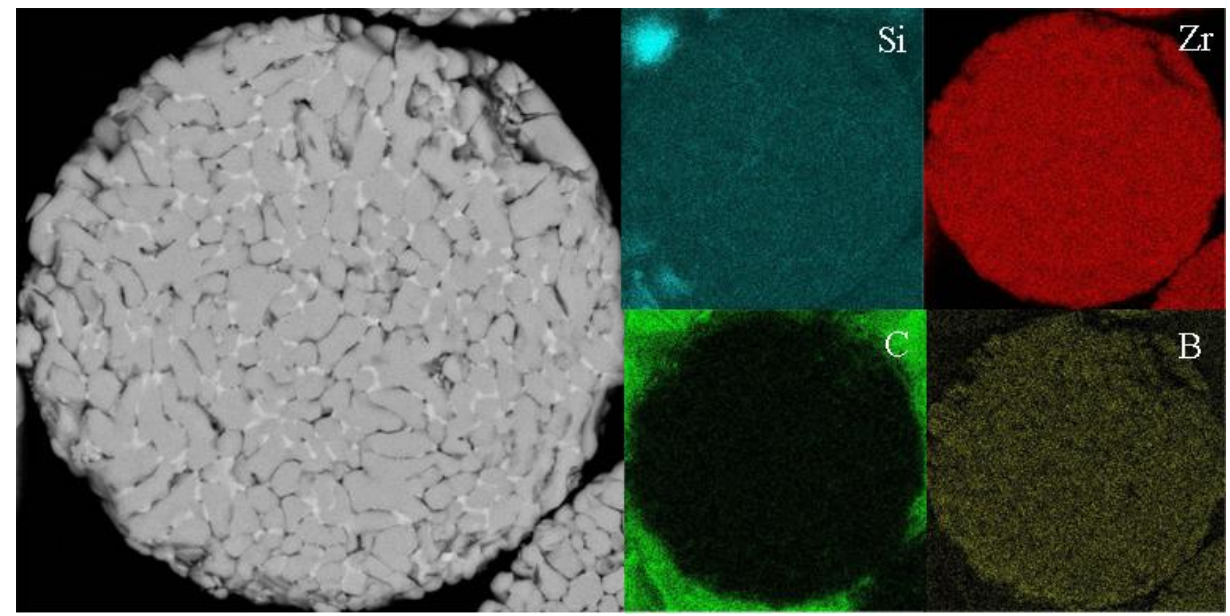

Figure 4 Elemental mapping of the powder particle after plasma spheroidization 
The elemental mapping (Figure 4) shows the distribution of the chemical elements in the powder particle volume. The distribution is relatively uniform across the powder particle. The microstructure consists of the lamellar eutectic-type structure with contrasting phases of $\mathrm{SiC}+\mathrm{ZrB} 2$. It can be seen, the majority of the particles are dense and there are no signs of the hollow particles, which means in addition to the spherical morphology and fraction, that the plasma spheroidized $\mathrm{ZrB}_{2}-\mathrm{SiC}$ powder meets the requirements for the additive manufacturing technologies, such as binder jetting.

\section{CONCLUSION}

In the present work, the dense spherical powders of the mixture $80 \mathrm{ZrB}_{2}-20 \mathrm{SiC}$ (vol\%) were obtained by mechanical mixing and plasma spheroidization.

The microstructure of the powder consist of the uniformly distributed lamellar-eutectic type of structure with contrasting phases, which in accordance with XRD can be determined as $\mathrm{ZrB}_{2}+\mathrm{SiC}$. There also a noticeable amount of nanoparticles as a result of the decomposition of the organic binder and smaller particles due to the overheating in plasma.

The spherical shaped dense particles can further be used for additive manufacturing technologies such as binder jetting.

\section{ACKNOWLEDGEMENTS}

This research was supported by Russian Science Foundation grant (project No 19-79-30002)

\section{REFERENCES}

[1] FAHRENHOLTZ, W.G., G.E. HILMAS, TALMY, I.G., ZAYKOSKI, J.A. Refractory diborides of zirconium and hafnium. J. Am. Ceram. Soc. 2007, vol. 90, pp. 1347-1364. https://doi.org/10.1111/j.1551-2916.2007.01583.x.

[2] OPEKA, M.M., TALMY, I.G., WUCHINA, E.J., ZAYKOSKI, J.A. CAUSEY, S.J. Mechanical, thermal, and oxidation properties of refractory hafnium and zirconium compounds. J. Eur. Ceram. Soc. 1999, vol. 19, pp. 2405-2414. https://doi.org/10.1016/s0955-2219(99)00129-6.

[3] SAVINO, R., DE STEFANO FUMO, M., PATERNA, D., SERPICO, M. Aerothermodynamic study of UHTC-based thermal protection systems. Aerosp. Sci. Technol. 2005, vol. 9, pp. 151-160. https://doi.org/10.1016/j.ast.2004.12.003.

[4] GUO, S.Q. Densification of ZrB2-based composites and their mechanical and physical properties: A review. J. Eur. Ceram. Soc. 2009, vol. 29, pp. 995-1011. https://doi.org/10.1016/i.jeurceramsoc.2008.11.008.

[5] ZIMMERMANN, J.W., HILMAS, G.E., FAHRENHOLTZ, W.G., MONTEVERDE, F., BELLOSI, A. Fabrication and properties of reactively hot pressed ZrB ${ }_{2}-\mathrm{SiC}$ ceramics. J. Eur. Ceram. Soc. 2007, vol. 27, pp. 2729-2736. https://doi.org/10.1016/i.jeurceramsoc.2006.11.074.

[6] ZHANG, H., JAYASEELAN, D.D., BOGOMOL, I., REECE, M.J., HU, C., GRASSO, S., LEE, W.E. A novel microstructural design to improve the oxidation resistance of $\mathrm{ZrB}_{2}$-SiC ultra-high temperature ceramics (UHTCs). J. Alloys Compd. 2019, vol. 785, pp. 958-964. https://doi.org/10.1016/.j.jlllcom.2019.01.208.

[7] HU, C., NIU, Y., HUANG, S., LI, H., REN, M., ZENG, Y., ZHENG, X., SUN, J. In-situ fabrication of ZrB2-SiC/SiC gradient coating on C/C composites. J. Alloys Compd. 2015, vol. 646, pp. 916-923.

https://doi.org/10.1016/j.jallcom.2015.05.205.

[8] HU, P. GUOLIN, W., WANG, Z. Oxidation mechanism and resistance of ZrB2-SiC composites. Corros. Sci. 2009, vol. 51, pp. 2724-2732. https://doi.org/10.1016/i.corsci.2009.07.005.

[9] SUN, S., LIU, Y., MA, Z., WANG, F., ZHU, S., GUO, J., HONG, C. Effect of powder pre-oxidation on the microstructure and ablation resistance of $\mathrm{ZrB}_{2}-\mathrm{SiC}$ coating. J. Alloys Compd. 2020, vol. 832, pp. 154881. https://doi.org/10.1016/j.jallcom.2020.154881.

[10] MONTEVERDE, F., SAVINO, R. Stability of ultra-high-temperature $\mathrm{ZrB}_{2}-\mathrm{SiC}$ ceramics under simulated atmospheric re-entry conditions. J. Eur. Ceram. Soc. 2007. https://doi.org/10.1016/j.jeurceramsoc.2007.02.201. 
[11] SUN, S., MA, Z., LIU, Y., LIU, L., WANG, F., LUAN, X. Ablation mechanism and properties of $\mathrm{SiO}_{2}$ modified $\mathrm{ZrB}_{2}-$ $\mathrm{SiC}$ coatings fabricated on $\mathrm{C} / \mathrm{C}$ composites via plasma spraying technology. Surf. Coatings Technol. 2020. https://doi.org/10.1016/j.surfcoat.2019.125132.

[12] MONTEVERDE, F., SAVINO, R., DE STEFANO FUMO, M. Dynamic oxidation of ultra-high temperature ZrB2-SiC under high enthalpy supersonic flows. Corros. Sci. 2011. https://doi.org/10.1016/i.corsci.2010.11.018.

[13] GUO, W.M., VLEUGELS, J., ZHANG, G.J., WANG, P.L., VAN DER BIEST, O. Effect of heating rate on densification, microstructure and strength of spark plasma sintered ZrB2-based ceramics. Scr. Mater. 2010. https://doi.org/10.1016/j.scriptamat.2010.02.002.

[14] MALLIK, M., KAILATH, A.J., RAY, K.K., MITRA, R. Effect of SiC content on electrical, thermal and ablative properties of pressureless sintered $\mathrm{ZrB}_{2}$-based ultrahigh temperature ceramic composites. J. Eur. Ceram. Soc. 2017. https://doi.org/10.1016/i.jeurceramsoc.2016.09.024.

[15] ZHANG, Z.-Y., DENG, G.-J., KONDO, N., YANG, J.-F., OHJI, T. Reactive hot pressing of ZrB2-SiC composites. J. Am. Ceram. Soc. 2004. https://doi.org/10.1111/j.1151-2916.2000.tb01558.x.

[16] SUN, S., MA, Z., LIU, Y., LIU, L., WANG, F., GUO, J. Induction plasma spheroidization of ZrB2-SiC powders for plasma-spray coating. J. Eur. Ceram. Soc. 2018. https://doi.org/10.1016/i.jeurceramsoc.2017.12.061.

[17] ZHOU, H., GAO, L., WANG, Z., DONG, S. ZrB2-SiC oxidation protective coating on C/C composites prepared by vapor silicon infiltration process. J. Am. Ceram. Soc. 2010. https://doi.org/10.1111/j.1551-2916.2009.03481.x.

[18] YANG, X., WEI, L., SONG, W., BI-FENG, Z., ZHAO-HUI, C. ZrB2/SiC as a protective coating for C/SiC composites: Effect of high temperature oxidation on mechanical properties and anti-ablation property. Compos. Part B Eng. 2013, vol. 45, pp. 1391-1396. https://doi.org/10.1016/i.compositesb.2012.07.007.

[19] REN, X., LI, H., CHU, Y., FU, Q., LI, K.Preparation of oxidation protective $\mathrm{ZrB}_{2}-\mathrm{SiC}$ coating by in-situ reaction method on SiC-coated carbon/carbon composites. Surf. Coatings Technol. 2014, vol. 247, pp. 61-67. https://doi.org/10.1016/j.surfcoat.2014.03.017.

[20] LU, W., QIAN-GANG, F., FENG-LING, Z. A novel gradient SiC-ZrB2-MoSi2 coating for SiC coated C/C composites by supersonic plasma spraying. Surf. Coatings Technol. 2017. https://doi.org/10.1016/j.surfcoat.2017.01.019.

[21] LI, C., NIU, Y., LIU, T., HUANG, L., ZHONG, X., ZHENG, X., DING, C. Effect of WB on oxidation behavior and microstructure evolution of ZrB2-SiC coating. Corros. Sci. 2019, vol. 155, pp. 155-163. https://doi.org/10.1016/i.corsci.2019.04.034.

[22] SUN, S., LIU, Y., MA, Z., ZHU, S., HONG, C., CHEN, H., MA, K. Fabrication of ZrB2-SiC powder with a eutectic phase for sintering or plasma spraying. Powder Technol. 2020. https://doi.org/10.1016/i.powtec.2020.06.019. 